\title{
TRUMP POLICY TOWARDS IRAN: CHALLENGES AND IMPLICATIONS
}

\author{
Arif Khan* \& Nargis Zaman $\dagger$
}

\begin{abstract}
A key foreign policy objective of President Trump during his election campaign was to reset, tighten and maximize his countering policies against Iran's destabilizing activities in the Gulf region. However, the challenges including the fate of Iran nuclear deal, ballistic missile program, support of terrorist's groups, US-Russia ties and Russian-Iran relations in Syria which the new administration faces to brought about against Iran, are much harder than his desired objectives. Trump's Middle East and Iran's policies presents an uncertain, complex and paradoxical scenario because the goals which he sets mark a clear deviation from his campaign promises against Iran. The global and regional actors such as Russia, Iran and Saudi Arabia will surely like to test Trump's policies and determination toward the Gulf region so that to achieve their anticipated goals.
\end{abstract}

Keywords: US, Iran, Saudi Arabia, Nuclear Deal, Russia-Iran ties and US-Russian connections.

\section{Introduction}

US foreign policy has always been shaped by both continuation and change. The incoming candidates especially from different parties often adopted unparalleled, divergent and often opposite policies to their outgoing predecessors which resulted in disastrous implications both for domestic and international politics. An important issue related to the foreign policy for the 
newly elected Donald Trump administration will be its policy towards Iran as was the case with the previous administration of Obama. Prior to the election, Trump made his policy intentions very clear about Iran but later after assuming the office of the President, he found this very difficult because the reality was far more difficult to achieve than his imagination. The Middle Eastern region has been dragged into a second cold war strategic scenario where Iran has gotten the support of Russia's Putin to advance her hegemonic influence over the Gulf countries. At the same time the new Trump administration will also shape its policies with regard to Iran to prevent it from developing a nuclear weapon, its terrorist activities and support of terrorist groups and its meddling role in the region.

The policies made by President Obama towards the Middle East and more especially Iran, was seriously criticized by the President-elect Donald Trump. During his election campaign, Trump severely criticized President Obama for doing business with Iran on the nuclear issue which resulted in the JCPOA. He labelled the nuclear agreement between US and Iran the worst deal ever negotiated in the history of United States. However these statements by President Trump cannot withhold the nuclear agreement because it is not a unilateral agreement but rather a multilateral agreement including the other five countries i.e. Germany, Russia, China, France and Britain. Sticking their favor with the nuclear deal against the harsh stance of President Trump, these countries viewed that multilateral diplomacy is still possible. For bringing peaceful solutions to the global issues which the great powers competition could not solve.

Trump policies towards Iran will adopt a different stance on a wide range of issues from that of the Obama eight years administration. Trump and his administration present ambiguity in their policies towards Iran and the major expected changes. He may face difficulties in implementation. First he used rhetoric against the landmark nuclear deal to dismantle it but later he peddled-back by saying that he would rather renegotiate the terms of the deal but it seems difficult because it will also invite frustration from the other members of the deal and US allies and would damage the credibility to honor the international agreements. Other area of concern for Trump administration is Iran's ballistic missile program which has been developed with the passage of time. Iran was put back under the layers of sanctions by the new Trump administration when it recently conducted ballistic missile tests which was regarded a violation of the UN Security Council Resolution. At this point of time, US President elect has decided to wipe out terrorism and extremism and has declared it primary objectives of American foreign policy. For attaining this objective president Trump might refresh and revive 
affairs with Russia. In this connection a telephonic talk (28 $8^{\text {th }}$ January, 2016) has already been made between the two presidents. They agreed to cooperate for bringing an end to the menace of terrorism and extremism and also agreed to maintain contact at earliest convenience in future. Russia has partnership with Iran in the fight against Daesh and it had also provided information from the field in Iraq and Syria. So, If in case US and Russia engage in dialogue with ease, Russia would certainly lobby for Iran to be accepted as a regional power in the Middle East. Although, there is an environment of mutual distrust between the two but US being the world super power and Iran being a major regional power would benefit a lot if engaged in positive relationship.

The war of words between Trump and Iran has escalated which has made the strategic scenario much complicated. President Trump's policies to counter Iran by dismantling or renegotiating the nuclear deal, conducting ballistic missile tests, Russia's support to intervene in Syria, IS and restoration of American leadership in the region are the challenges with which the new Trump administration is faced. The most important question here is that what impelled the new Trump administration to revise the previous Obama administration's policies towards Iran when there had been occurred some improvements in their worst relations. Will these policies bring some tangible results for the US and what would be the impacts of these policies on Iran?

\section{Causes to Replace Old Policies into New Policies}

The new American administration is well aware of the growing regional influence of Iran which the previous Obama government took lightly handled. In contrast to the previous US government, the Trump administration has enhanced its deterrence policy against the Islamic Republic to counter its meddling in the affairs of the region. Although Trump's decision to revise policies on Iran's nuclear agreement with United States and other five major countries will be a big challenge for him and his administration because the JCPOA (Joint Comprehensive Plan of Action) was not a unilateral agreement but rather a multilateral agreement (Gharleghi, 2018). To stop Iran from attaining a nuclear weapon, President Donald Trump will surely tighten his policies against Iran. He took this stance on the grounds that, even if Iran honors the terms of the deal, it will easily attain the nuclear weapon because after few years later, when the limitations on the Iranian nuclear program are lifted, Iran will be able to easily develop military nuclear weapons (Kam, 2017). Trump proposed that 
strict monitoring is required on daily basis to check the status of the Iranian nuclear arsenals. The International Atomic Energy Agency (IAEA) reports insist that no other country has ever been closely monitored than Iran. It reported that Iran has stopped working on its uranium enriching program and is duly abiding the rules and conditions of the nuclear agreement (Maria, 2017).

Another factor which led the President Trump and his administration to replace the policies of his predecessors is the failure of the President Obama to stop the Iranian missile program. The missile program of Iran was not incorporated in the nuclear talks or in the final nuclear agreement due to the refusal of Iran which subsequently enabled them to carry out several flashy missile tests and managed to extend the range and accuracy of the missile target. Trump criticized that it will not only make it possible for Iran to hit small targets but also Israel, other Gulf countries and even the United States in the future. He proposed that the existing sanctions on its missile program are not severe enough to force Iran to downsize its nuclear program (Hurtung, 2018)

The increasing Iranian military capabilities have raged fear in US's new establishment. Iran is going to conclude a large arms deal with Russia which is worth more than $\$ 10$ billion instead of Security Council Resolution forbidding Iran from arms supplies until 2020. The completion of this deal will help strengthen and improve the overall quality and capabilities of Iranian air force against its rivals including the Arab world, Israel and the US (Fishel, 2016).

\section{Trump and the Fate of the Historic Nuclear Deal}

President Donald Trump has repeatedly promised to scrap the nuclear deal with Iran and regarded it as the worst deal ever negotiated in the history of United States. Prior to the election, he used his harsh rhetoric against the JCPOA and criticized President Obama for giving relief to the Islamic Republic. He also showed his commitment before audiences that he would work on nuclear sanctions renegotiate and refine the terms of the nuclear deal to make it much tougher on Iran (Meijer, 2017).

The repurcussions of withdrawing or ammending the deal will be very high both diplomatically and politically for Prsident Trump because it will invite frustration from both allies and rivals and will undermine the integrity of the US to honour the international agreements that they negotiated with other countries. Iran and Russia have common goals in Syria i.e to save Bashar Asad government against the Sunni backed rebel groups and to 
restore Russian influence by diminishing US standing in Syria. It is said that to resolve Russian disagreements with US in Europe and Middle East, President Trump might offer concessions to Russia in Syria in return for Russian concessions in Ukraine and Europe. This bargaining by President Trump will obviously melt the ice with Iran on the nuclear deal and will result in greater regional influence of Iran in the Gulf countries. However it will also lead to frustration and tension between US and her allies like Saudi Arabia and Israel who are constantly pushing hard the US to renegotiate the terms of the deal so to undermine the rising hegemonic influence of Iran in the region. Russian support of Iran to increase military and political intervention in Syria, Yemen, Iraq, terrerist acts, ballistic missiles program and the nuclear deal have created deep concerns in US allies (Eytan,2016). These developments have turned Middle Eastern strategic environment into a second cold war scenario where the two super powers have confronted each other for their strategic objectives.

Similarly President Trump's harsh stance to scrap the deal may possibly complicate and undermine the alliances of the United States with other major economic powerhouses (such as Japan, India, South Korea) which are not the part of the agreement but they have a lot to get from JCPOA's continuation. It will also isolate US from Iran and these countries and might serve as a great policy concern for the US foreign policy and security establishment to stop crushing the nuclear deal (Wagner, 2017).

Trump's antagonism against Iran's nuclear arrangement will also intensify the political atmosphere in Tehran by strengthening the influence of radical hardliners against the moderate reformer Hassan Rouhani who signed the JCPOA with US. President Hassan Rouhani in his re-election campaign used the nuclear deal and improvement in relations with US as his biggest achievements which would serve Iran's economic interests. But the accelerating war of words between the US and Iran has casted its long shadows on these achievments which may present opportunities to the hardliners to convince the undecided section of the Iranian population that the results connected with the deal are meager which might weaken his position in the election campaign. Even Supreme Leader Ayatull Allah Khamenei criticized the Rouhani administration in November 2016 pointing to the renewal of sanctions on Iran by the US congress in the advent of conducting ballistic missiles tests. Trita Parsi, of the National IranianAmerican Council said that the travel ban on the seven muslim countries including Iran could also work against President Hassan Rouhani re-election bid (Fattahi, 2017). However these arguments proved weak and false when he was re-elected for a second term as the president of the Islamic Republic. 
Although President Trump adopted tough stance against the Nuclear Deal to scrap it but it seems top difficult to take into account his imagined views with regard to the fate of JCPOA. However there might be three possibilities for the Trump and his administration to adopt on the future of JCPOA with Iran. First, to keep the status quo unchanged; it is possible that without taking concrete actions against the nuclear deal and the current US sanctions, he may uphold his stance of holding Iran; responsible for altering or cancelling the deal. Second, to reimpose sanctions on Iran, the US may be able to assert that Iran has violated the terms of the JCPOA which would enable the US to "police" the contract very toughly. Third President Trump could bring back Iran to the negotiating table by threatening to reimpose the relaxed US sanction laws or the new ones and also roll-back the primary US sanctions on the table (Zenlick \& Cripps, 2017)

Recently in July 2017, Trump adopted his administration certified in congress that Iran is technically complying with the nuclear deal in accordance to the rules set by the International Atomic Energy Agency (IAEA) and said that Iran can enjoy nuclear sanctions relief. The law has given the administration the authority to check the status of Iranian nuclear program after every ninety days. Although it is a positive development with regard to the nuclear deal but instead President Trump and his administration are pushing hard to strictly enforce the deal by imposing additional restrictions and eliminating aspects of the deal which allows Iran to resume some nuclear production after 10 years (Bennett \& Bierman, 2017). A day after the certification by congress, President Trump and his administration slap new sanctions on 18 Iranian individuals, groups and networks for nonnuclear acts such as supporting its ballistic missile development. These sanctions target seven groups and five people that support Iran's military or its Revolutionary Guard, a transnational criminal group plus also associated three people with it and two more groups associated with ballistic missile program and freezed their assets to prevent doing business with them. (Gehrke, 2017).

There are too many hidden hands working in the favor of JCPOA and also against its nullification to happen. Trump has little to do with a more hard-line stance against Iran because Trump will be more concerned with a foreign policy perspective to develop deep cooperation with the Kremlin to counter IS instead of Assad government and his allies in Syria, a strategy which will unofficially lead to more US-Iran alignment even if that is not Trump's intention(Wagner, 2017). President Trump issued several statements to tear up the nuclear deal when he was running his election bid 
but it seems unrealistic because till this time in office, he has not done anything to scrap the deal.

\section{Trump's Alliance Politics with Saudi Arabia to Counter Iran}

Iran's utmost support and favor for the militant and terrorist groups in Syria, Yemen, Iraq benefit it in numerous ways. It enables Iran to support the key allies like the regime of Bashar al-Asad in Syria. It also gives Tehran leverage against regional rivals like the Kingdom of Saudi Arabia and also strengthens pro-Iran voices in the region, increasing Iran's influence in some capitals and backward areas of several countries. Finally, stable countries are more sensitive to the threat of Iranian terrorism and to deter the threat, they must sought such policies which could enhance their defense power. President Donald Trump and his administration is pushing hard to counter Iran's malign activities and rising intervention in Gulf region on every front by enhancing the security, strength and military capabilities of the states such as Saudi Arabia, UAE, Egypt, Turkey and Israel. These countries had their reservations against the previous Obama administration for not effectively tackling the threats they faced from the Iranian activities in the region (Thomas, 2017)

To enhance the security and detrence power of her allies, President Trump signed an arms deal worth nearly $\$ 110$ billion with Saudi Arabia to counter Iran's malign activities and growing influence in the region (Cassidy, 2017). This arms deal include the flow of US ballistic missile systems to Saudi Arabia and the most vital thing is that this deal will also include the renewed sale of precision-guided munitions that were previously blocked under the administration of Obama due to the fears that the Saudis might use it for the civilian targets in Yemen. The deal will also enable the Kingdom to purchase the Patriot and Terminal High Altitude Area Defense (THAAD) anti-missile technologies that will thwart Iranian rocket (Watkins, 2017). This info graphic uses the Stockholm International Peace Research Institute's "Trend-Indicator Values" (TIV). These are based on the known unit production cost of weapons and represent the transfer of military resources rather than the financial value of the transfer. 


\section{Saudi Arabia is the biggest Buyer of US arms}

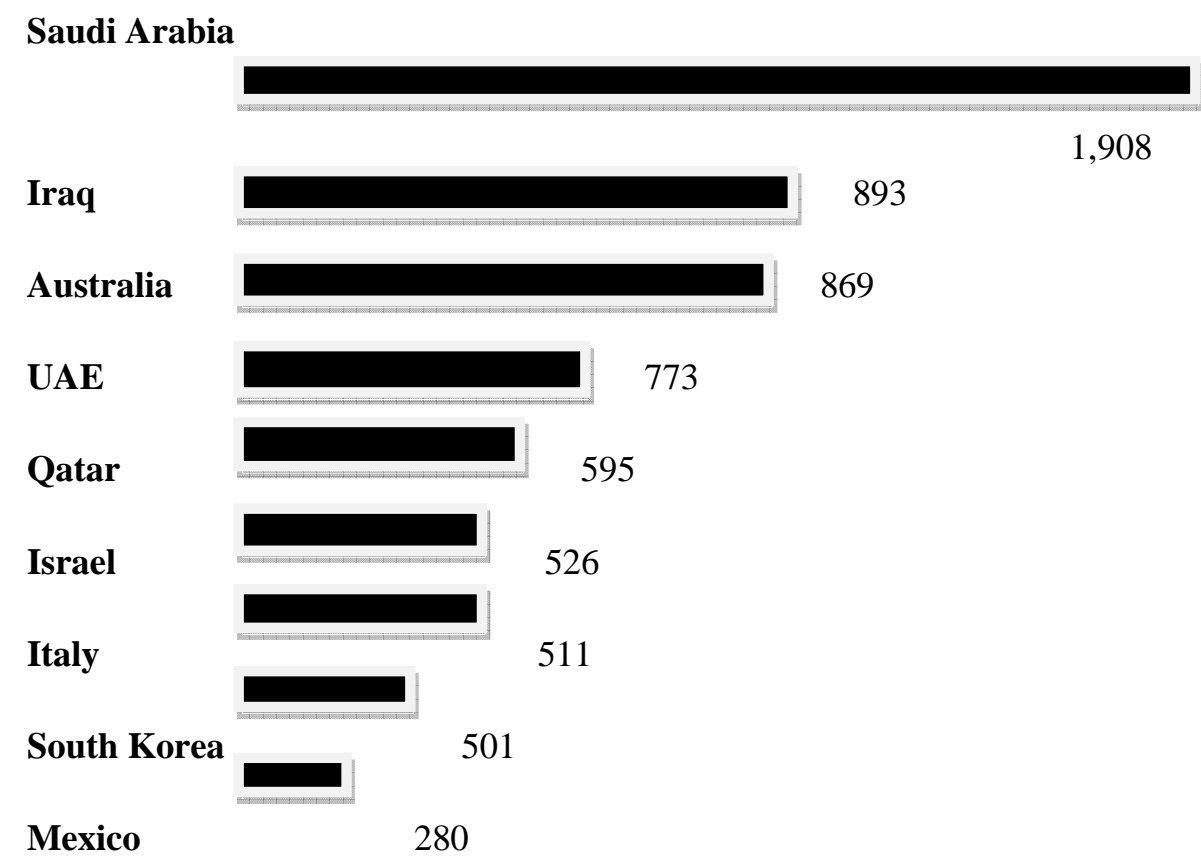

Source: Stockholm International Peace and Research Institute.

Although this policy may help US to counter the malign activities of Iran domestically by increasing the military capabilities of her regional allies but the implications of this defense deal for the region will be drastic because it could also prompt an arms race among other countries of the region. Recently relations between Qatar and the Saudi Kingdom got worse due to the later's support for Iran's terrorist groups. Like Saudi Arabia, President Trump openly accused Qatar for sponsoring terrorism. He said on $9^{\text {th }}$ June in Rose Garden that "unfortunately the state of Qatar has been historically a funder of terrorism at a very high level" and we have to stop it. But this scenario changed just after five days of President Trump accusation of Qatar when Defense Secretary James Mattis finalized a \$12 billion arms deal with Qatar for 36 F-15 fighter jets (Ward, 2017)

These messages mixed with uncertainity and confusion have made the Gulf region more complex, complicated and sensitive because the proxy wars in the Middle East would last for years which might enhance the desire of these countries to pursue even more eagerly the sale of these weapons which could also become a jewel of future American arsenals and weapons 
because the profit will boost the US economy and will help President Trump to make America Great again because a large amount of American economy came from its advanced military technology. The Trump Administration did entail Kingdom of Saudi Arabia to purchase \$750 million worth of U.S. training to help mitigate civilian casualties in Yemen. President Trump also successfully pushed Saudi Arabia to lift the blockade for 30 days to allow U.S. supplied cranes to be installed at a key port of entry point in Yemen The ever rising Sunni-Shia ethnic and sectarian rivalries led by Saudi and Iran respectively coupled with these latest weaponry power could precipitate the region in devastating civil wars.

U.S. Munitions and Firearms for Saudi Arabia and U.A.E. 2017

\begin{tabular}{|l|c|}
\hline \multicolumn{1}{|c|}{ U.S. Weapons System } & Dollar Amount \\
\hline \multicolumn{1}{|c|}{ Saudi Arabia } & \\
\hline Joint Direct Attack Munitions & $\$ 118,304,843$ \\
\hline FMU-152A/B Joint Programmable Bomb Fuze System & $\$ 95,250,001$ \\
\hline $\begin{array}{l}\text { Paveway II and Ill, Enhance Paveway II and Ill, and } \\
\text { Paveway IV Weapon Systems }\end{array}$ & $\$ 298,430,237$ \\
\hline Various calibers of firearms ammunition & $\$ 98,500,000$ \\
\hline Total & $\$ 610,485,081$ \\
\hline \multicolumn{1}{|c|}{ United Arab Emirates } & $\$ 7,918,327$ \\
\hline M4 fully automatic carbines 5.56x45 NATO & $\$ 2,644,360$ \\
\hline Bolt action rifles \& suppressors & $\$ 1,469,925$ \\
\hline M16A4 rifles, spare parts, accessories, and training & $\$ 11,000,000$ \\
\hline Various machine guns and spare barrels & $\$ 25,591,730$ \\
\hline $\begin{array}{l}\text { 5.56mm upper receiver assemblies, barrel assemblies, } \\
\text { and accessories }\end{array}$ & $\$ 48,624,342$ \\
\hline Total
\end{tabular}




\section{Sanctions Policy of Donald Trump against the Islamic Republic of Iran}

US sanctions and all the attempts to attain the multilateral and international imposition of sanctions on Iran have been considered in different ways a great policy tool in the component of US-Iran policy since Iran's 1979 Islamic Revolution that fell the Shah of Iran, the ally of US. In order to stop the acts of terrorism, militant activities and strategic power show in the Middle East, US sanctioned Iran in 1980s and 1990s. In the mid 2000s, international and US sanctions on Iran largely focused on ensuring that the Nuclear program of Iran is for purely civilian purposes. The International community from 2010-2015, cooperated intimately to pursue Iran to limit its nuclear program. Still, sanctions against Iran have numerous objectives and address many perceived threats from Iran at the same time.

The re-imposition of US sanctions has begun to damage the economy of Iran as main companies started to exit the Iranian economy rather than risk being penalized by the United States. Sharp decrease has been observed in Iran's oil exports and difficulties in paying Iran for the oil with hard currency are also evident. The value of Iranian currency is also going downwards and economic unrest has been sustained, although not to that extent that the regime is threatened (Katzman, 2018).

\section{Iran's Oil and Gas Export Exports in Billion US Dollars}

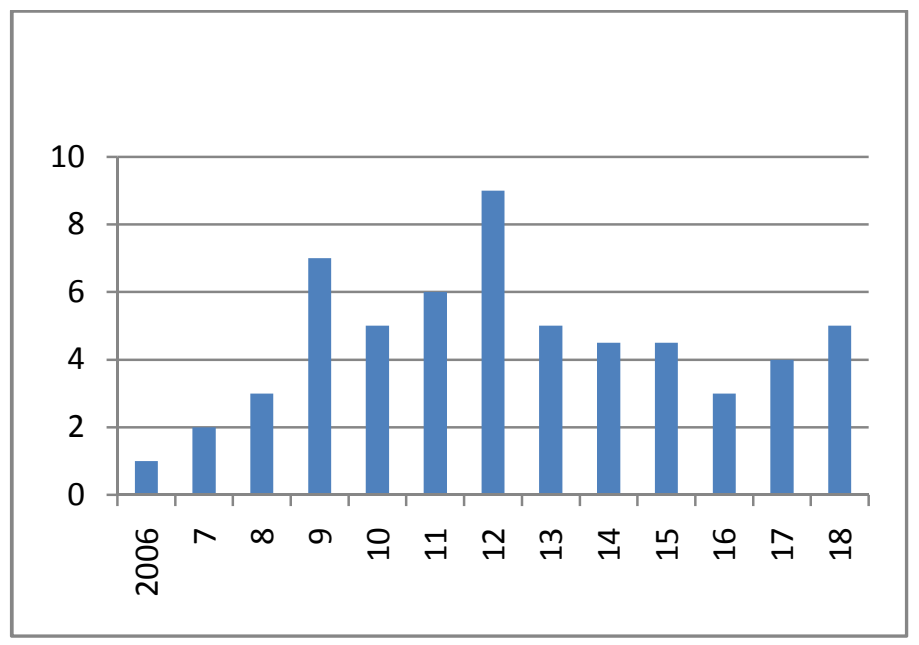

Source: Central Bank of the Islamic Republic of Iran, IATBXOIL Index 
As the administration of the Donald Trump was deciding to leave the nuclear deal, the Iranians fearing for an economic crash rushed to stockpile the foreign currency.

The currency of Iran, Riyal has lost half of its value since January, and dollar has climbed to its high value of 100,000 Riyals in the unofficial market (Salehi, 2017)

The Administration of the Donald Trump in order to counter the "malign activities" of Iran has adopted a policy and its behavior, primarily based on reducing the financial resources of Iran. The Administration of the US President also argued that the Joint Comprehensive Plan of Action failed to deal with regional activities of Iran. On the basis of these grounds, President Donald Trump decided to withdraw the position of United States from the JCPOA on $8^{\text {th }}$ May, 2018, and proclaimed that US would reimpose sanctions on Iran. (Katzman, 2018)

\section{Implications of Trump's Policies on the Region}

Trump did not formulate any coherent policies towards the Middle East generally and Iran particularly, rather they presented an imprecise and complex posture which may result in internal contradictions for the repressive regimes because they are unstable and unable to check their internal repression which will lead to aggravate their internal challenges. Regarding Iran, the administration has been sending mixed signals, making it difficult to understand its intended policy. Trump's transactional approach towards alliance politics and mixed messages against Iran will weaken his ally's efforts to counter Iran's destabilizing activities across the region and thus he will not be able to fulfill the desired challenges, evasions and demands of his regional allies (Lynch, 2013)

Another contradictory policy which Trump's administration designed would threaten the global security environment through his extremist approach towards Islam. The proposed ban on Muslim immigration will rise the conflict with the Islamic world which will lead to extreme hatred against the US and will also give birth to jihadist extremists. Trump's advisers have labelled the mainstream Islamist movement as a terrorist organization which regularly competes in Arab elections. It will also undermine President Donald Trump's strategy to form an alliance to deter Iranian influence in the region (Noriega, 2016)

Trump criticized Obama and Clinton for military intervention in Iraq, Libya and Yemen because it did not meet the proposed objectives and instead gave a heavy blow to its economy by spending billions of dollars. As a result 
of this policy change, Saudi war in Yemen seems unlikely to change U.S. policies towards the Middle Eastern region and will leave Riyadh alone to fight its own local wars, no matter how meaningless and destructive. This policy will also invite a huge economic profit for US by selling vast quantities of arms to these countries to support their war effort (Lynch, 2017).

Another area of concern for President Trump will be the previous US policy of interventionism which trapped it completely in the Middle East and the way to escape seems difficult and to fulfill his election campaign promises, President Trump will likely attempt to follow the policies of Obama's administration to combat radical Islam and to control the meddling of Iran, its support of terrorist groups, its nuclear ambitions and ballistic missile program which is a key policy concern for US and her allies (Lynch, 2017).

Trump's desire to improve relations with Russia to defeat ISIS and resolve the Syrian issue without destroying Iran and Assad's government in Syria will have direct impacts on his relations with Gulf States such as Saudi Arabia because it will further Iran's dominance in the region at the cost of these states. It is illogical that on one hand Trump signed an arm agreement with Saudi Arabia for the purpose to create a strong deterrence wall against Iran's destabilizing influence in the Gulf region and on other hand leave Iran with free hands to fight the war with Assad against the Sunni rebel groups just to please Russian Putin (Bendix, 2017).

Trump's desire to please Russia by turning aside from Middle Eastern politics will certainly weaken other regional powers efforts such as Saudi Arabia to contain Iran's influence and instead will lead to complexity and uncertainty because they will consider it simply a granting victory to Iran and Assad at the cost of her allies (Beauchamp, 2017). Also Trump's main concern to "make America great again" could reduce his personal involvement in Middle Eastern issues and instead will provide enough place for Russia and Iran to strengthen their influence in the region which may likely to leave President Assad in power still and instead the Sunni camp led by Saudi Arabia to accept the coalition of US, Russia and Turkey to crush the roots of ISIS in the near future (Guzansky \& Michael, 2017).

\section{Conclusion}

Trump's policies towards Middle East and Iran present an incoherent and even more complex scenario which continue to puzzle experts and decision makers around the globe. Trump's harsh rhetoric against the nuclear deal to scrap it proved weak like the noise of an empty drum which simply resulted in making the strategic environment like a hot cake. 
President Donald Trump ran his election campaign on various policy objectives. He constantly criticized Iran's destabilizing activities in the Middle East and showed his utmost desire to undermine and counter Iran's regional influence. During the early days of his Presidency, he showed a hard stance towards the Islamic Republic. Trump's extremist approach towards the Muslims around the globe and his immigration ban will certainly weaken US's efforts to build an alliance system against Iran in the Gulf region, among other costs. Similarly, this policy build up will make Iran more likely to work with anti-American local groups. Trump and his administration need to be more careful in its rhetoric against allies and enemies because they both will consider him as unpredictable, unreliable and may simply avoid the signals which they do not like and will lead to misunderstandings and heavy costs for the United States.

Washington's decision to focus on ISIS but not Assad has given Russia and Iran a free hand to change the balance of power in Syria. It has created suspicions in US allies such as Saudi Arabia and Israel with raising questions about whether the United States cares about the power struggle in the region between the Gulf Arab states and Iran, in which Moscow has chosen to back Tehran's interests. Continued passivity from the Trump administration will be considered as acquiescence to Russia and Iran's regional plans to advance their influence at the cost of Arab Gulf States which will also expose the unjustified pretext and hypocritical nature of Trump towards her allies.

Trump and his administration need to closely work with and support the opposition Sunni forces against the Asad government and his allies in Syria because it will develop trust building and cooperation between US and her Gulf allies which will strengthen their strategic position in Syria against the opponents and will also help to defeat Islamic State. It will also provide America and her allies more possibilities to get an upper hand in a future Syria. Finally, the administration of Donald trump must set a realistic policy approach for success against Iran because Iran's strategic position and its desire to shape the Middle Eastern politics in its own favor will certainly persuade it to work with a range of terrorist and militant groups to advance her policies in the region. So it is a challenging task for Trump and his cabinet team that how they will contain Iran. Only better and clear US policy can reduce the possibility of Iran's malign activities because without commitment and sincerity, Trump's policies to contain Iran will lead only to a complicated and uncertain strategic environment which may instead weaken US power structure in the Middle East not Iran. 


\section{References}

Beauchamp, Z. (2017). Trump's "new strategy" on Iran is neither new nor a strategy. USA. Vox.

Bennett, B. and Bierman, N. (2017). Trump administration says Iran is in compliance with the nuclear deal. USA. Los Angeles Time.

Cassidy, J. (2017). Tiller son: Saudi Arms Deal meant to counter Iranian influence. USA.VOA News.

Eytan, G. ( 2016). Reassessing American Interests in the Middle East. Israel. BESA Center Perspectives.

Fishel, J. (2016). Could Donald Trump Really Dismantle the Nuclear Deal. USA. ABC New.

Fattahi, K. (2017). The rising risk of showdown between Trump and Iran. Iran. BBC Persian Service.

Gehrke, J. (2017). US slaps new sanctions on Iranian groups and individuals. USA. Los Angeles Times.

Gharleghi, B. (2018). The JCPOA and Iran's Economic Future. Berlin. DOC institute of research.

Guzansky,Y. and Michael, K. (2017). Trump Presidency and the Pragmatic Sunni Regimes. Israel. The Institute for National Security Studies.

Hanke, S. H. (2012). Iran: Down, But Not Out (Publication). Washington, D.C: Cato Institute.

Hartung, W. (2018). Trends in Major Arms Sales in 2017: Comparison of the Obama and trump Administration.USA. Security Assistance Monitor.

Kam, E. (2017). A Possible Trump Administration's Iran Policy: Constraints and Options". Iran Matters. USA: Belfer Center.

Kam, E. (2017). A Possible Trump Administration's Iran Policy: Constraints and Options". Iran Matters. USA: Belfer Center

Katzman, K. (2018). Iran Sanctions. Ian Watch. Congressional Research Service.

Katzman, K. (2018). Iran's Foreign and Dfense Policies. Iran Watch. Congressional Research Service.

Lynch, M. (2013). The persistence of Arab anti-Americanism: In the Middle East, haters gonna hate. USA. Foreign Affairs.

Lynch, M. (2017). Belligerent Minimalism: The Trump administration and the Middle East. USA. The Washington Quarterly.

Maria, F. C. (2017). The Trump Administration Policies towards Iran. New York. The Market for Ideas Journal. 
Meijer, H. (2017). Strategic Implications of Donald Trump's Election. USA. IRSEM.

Noriega, D. (2016). Here's how Trump could take down the Muslim civil rights groups. New York. Buzzfeed New.

Thomas, C. (2017). Arms Sale in the Middle East: Trends and Analytical perspective for US Policy.USA. Congressional Research Services.

Salehi, S. (2017). Sanctions Impacts on the Exchange Rate (2005-2013, Iran). Brussels. Vrije Universitite.

Ward, A. (2017). Trump called Qatar a terror sponsor. He sold them fighter jets five days later. USA. VOX. Zenlick, K. and Cripps, S. B (2016). Trump and the Implications for US Sanctions on Iran. USA. New York Law Journal.

Wilkinson, T. ( 2016). Trump's Plans to Scuttle or Amend the Iran Nuclear Deal Remain a Work in Progress. USA. Los Angeles Times.

Watkins, T. (2017). AFP, US-Saudi arms mega deal looks to counter Iran. Washington DC. Al-Monitor: The Pulse of the Middle East. 